BIOMA 11 (1), 2015

Biologi UNJ Press

ISSN : 0126-3552

\title{
PENGARUH PEMBERIAN JENIS DAN KONSENTRASI AUKSIN TERHADAP INDUKSI PERAKARAN PADA TUNAS Dendrobium SP SECARA IN VITRO
}

The Effect of Types and Concentrations of Auxin on Rooting Induction on Dendrobium sp Bud in In Vitro

\author{
ANISAH SULASIAH, CHRISTIANI TUMILISAR \& TUTI LESTARI \\ Jurusan Biologi FMIPA Universitas Negeri Jakarta (UNJ). Jl. Pemuda No. 10 Rawamangun, Jakarta Timur. 13220. \\ Indonesia. \\ E-mail: anisasulasiah89@gmail.com \\ Tanggal publikasi online:
}

\begin{abstract}
Dendrobium orchids are the most widely grown because it has the advantages of easy to maintain and most easily grown. Induction of rooting in bud of Dendrobium sp by giving the different types and concentrations of auxin is one of many ways to get plantlets in large quantities and relatively quick time. The purpose of this research is to obtain the types and concentrations of auxin is the best in inducing rooting in bud of Dendrobium sp. This research was conducted at the Tissue Culture Laboratory, Department of Biology, Faculty of Mathematics and Science, State University of Jakarta on February to June 2013. The method used was description and experimental, the design of a factorial with two groups consisting of one control group and one experimental group for the provision of the types and concentrations of auxin on root induction in Dendrobium sp bud with each group consists three replications. Analysis of the data using three-way anova. Based on this research, Dendrobium sp bud induced by the different types and concentrations of auxin showed a distinct influence on the growth of bud in qualitative and quantitative characters. Qualitative data on root induction, shows that there is a root that grows one and two roots and shoots are green, white and brown. The results based on quantitative data showed that the bud of Dendrobium sp induced by auxin type 2,4-D and concentration of $0.75 \mathrm{ppm}$ had an average number higher root length compared with the type of auxin IAA and NAA. Dendrobium sp bud are planted in the medium by the addition of auxin type of IAA and NAA at a concentration of $1.25 \mathrm{ppm}$ has an average number of roots better than the auxin type 2,4-D.
\end{abstract}

Keywords: Dendrobium sp, Types and Concentrations of Auxin, Rooting Induction

\section{PENDAHULUAN}

Tanaman anggrek dengan segala keunikannya telah memukau dan menarik perhatian para botanis sejak dua abad yang lalu. Tanaman anggrek ada yang tumbuh di tanah dan ada juga yang dapat tumbuh secara epifit. Anggrek yang tumbuh secara epifit biasanya menumpang pada tanaman lain 
tetapi tidak merugikan tanaman yang ditumpanginya. Salah satu jenis anggrek yang memiliki keragaman bentuk dan warna bunga yang sangat unik adalah Dendrobium. Keunikan inilah yang membuat anggrek Dendrobium mempunyai nilai ekonomis tinggi. Dendrobium merupakan jenis anggrek yang paling banyak ditanam masyarakat awam. Selain keunikan dan keindahan bunganya, Dendrobium juga harganya relatif lebih murah (Indarto, 2011). Dendrobium merupakan salah satu jenis tanaman anggrek yang pemeliharaannya tidak sulit.

Perbanyakan Dendrobium secara konvensional melalui anakan membutuhkan waktu yang relatif lama pertumbuhannya. Oleh karena itu dilakukan alternatif lain dalam perbanyakan Dendrobium dengan cara teknik kultur jaringan (in vitro). Perbanyakan Dendrobium dengan teknik kultur jaringan (in vitro) dilakukan untuk memperoleh bibit tanaman dalam jumlah banyak, waktu yang dibutuhkan untuk memperoleh bibit tanaman tidak terlalu lama serta sifat unggul dari tanaman induk dapat dipertahankan. Tunas Dendrobium yang digunakan dalam penelitian ini berasal dari kultur biji anggrek, kemudian berkembang menjadi protocorm dan tumbuh menjadi tunas. Pertumbuhan tunas dalam penelitian ini tidak diikuti dengan pertumbuhan akar dan hanya tunas saja yang terus tumbuh dan bertambah banyak. Penelitian ini dilakukan sebagai penelitian pendahuluan di Laboratorium Kultur Jaringan Jurusan Biologi Fakultas Matematika dan Ilmu Pengetahuan Alam Universitas Negeri Jakarta.

Agar tunas Dendrobium dapat membentuk plantlet diperlukan usaha untuk menstimulasi pertumbuhan akar. Untuk menginduksi akar dalam penelitian ini, media yang digunakan akan diberikan perlakuan zat pengatur tumbuh yang dapat menginduksi akar pada tunas Dendrobium sp berupa auksin. Selain zat pengatur tumbuh juga ditambahkan air kelapa pada media perlakuan penginduksian akar. Tujuan dari penelitian ini adalah untuk mendapatkan jenis dan konsentrasi auksin yang baik dan cocok untuk penginduksian perakaran pada tunas Dendrobium sp.

\section{BAHAN DAN METODE}

Penelitian dilaksanakan di Laboratorium Kultur Jaringan Tanaman, Jurusan Biologi FMIPA Universitas Negeri Jakarta yang terletak di Kampus B, Jakarta Timur pada bulan Februari-Juni 2013. Bahan yang digunakan berupa larutan stok zpt (IAA; NAA; 2,4-D dan BAP), tunas Dendrobium sp, media Murashige-Skoog (MS sebagai media kontrol), media penginduksian akar (MS+IAA, MS+NAA dan MS+2,4-D), alkohol 70\%, spirtus, glukosa, agar-agar, tissue, aquadest steril, korek api, karet gelang, plastik penutup botol tanam, kertas yellow pages, klorox, kertas label, kertas saring, air kelapa muda dan $\mathrm{pH}$ meter.

Tunas Dendrobium sp yang digunakan merupakan koleksi tunas yang ada dalam Laboratorium Kultur Jaringan, Jurusan Biologi, Fakultas Matematika dan Ilmu Pengetahuan Alam, Universitas Negeri Jakarta. Proses penanaman dilakukan secara aseptik dalam Laminar Air Flow Cabinet dengan menggunakan alat yang steril. Tunas Dendrobium sp kemudian diletakkan pada media kultur yang telah disiapkan. Setiap botol ditanami 2 tunas Dendrobium sp. Selanjutnya botol-botol yang telah diletakkan dalam ruang kultur dengan suhu $20^{\circ} \mathrm{C}$. Tunas Dendrobium sp diamati selama satu bulan di laboratorium Kultur Jaringan, selanjutnya diamati karakter secara kuantitatif (waktu inisiasi akar, panjang akar, jumlah akar dan berat total tunas) dan secara kualitatif. 


\section{HASIL DAN PEMBAHASAN}

\section{Waktu Inisiasi Akar}

Akar tumbuh pada hari ke-27 dan hari ke-30 setelah masa tanam. Pada hari ke-27 dan hari ke-30 secara visual akar dan tunas yang tumbuh didominasi oleh warna hijau, dan secara statistik berbeda nyata pada perlakuan konsentrasi auksin sebesar 0 ppm; 0,75 ppm; 1,00 ppm dan 1,25 ppm, Pada konsentrasi auksin sebesar 0 ppm dalam media tanam terdapat adanya akar yang tumbuh yaitu pada media A0B1. Pada media tanam tersebut terlihat adanya pertumbuhan akar. Hal ini kemungkinan diduga adanya auksin endogen dalam tunas Dendrobium sp yang mampu merangsang pertumbuhan akar pada tunas dalam penelitian ini. Jenis auksin IAA, NAA dan 2,4-D yang ditambahkan dalam media tanam menunjukkan hasil yang beda nyata terhadap rata-rata waktu inisiasi akar pada tunas Dendrobium sp.

Tabel 1 Bobot pankreas tikus Wistar pada berbagai variasi dosis pemberian minyak trans

\begin{tabular}{ll}
\hline Dosis minyak trans & Bobot Pankreas $(\mathrm{g})$ \\
\hline Kontrol & $0.30 \pm 0.066$ \\
$20 \%$ energi total pakan & $0.38 \pm 0.050$ \\
$40 \%$ energi total pakan & $0.32 \pm 0.121$ \\
$60 \%$ energi total pakan & $0.30 \pm 0.043$ \\
\hline
\end{tabular}

Hasil visualisasi pengamatan warna akar Dendrobium sp pada waktu inisiasi akar dapat dilihat pada Tabel 1. Pada hari ke-27 setelah masa tanam warna akar yang tumbuh didominasi oleh warna hijau dengan persentase sebesar 36,8\% dan terdapat pada media A3B0 (IAA 1,25 ppm), A2B1 (IAA 1,00 ppm), A3B1 (IAA 1,25 ppm), N1B0 (NAA 0,75 ppm), N2B0 (NAA 1,00 ppm), D2B0 (2,4-D 1,00 ppm) dan D3B1 (2,4-D 1,25 ppm). Pada hari ke-30 setelah masa tanam akar yang berwarna hijau yang mulai muncul pada tunas Dendrobium sp menunjukkan hasil bahwa akar berwarna hijau juga lebih dominan dengan persentase sebesar 10,5\%, jika dibandingkan dengan warna akar yang lain yang tumbuh pada tunas yaitu terdapat dua media perlakuan N1B1 (NAA 0,75 ppm) dan N2B1 (NAA 1,00 ppm).

Media perlakuan dengan penambahan jenis dan konsentrasi auksin menunjukkan awal munculnya akar pada tunas Dendrobium sp berpengaruh pada waktu inisiasi akar (pada hari ke-27 dan hari ke-30 setelah masa tanam). Hal diatas sesuai dengan pernyataan Macdonald (2002) yang menyatakan bahwa kegunaan dari hormon pengakaran yaitu secara keseluruhan meningkatkan persentase pengakaran, mempercepat inisiasi pengakaran, meningkatkan jumlah dan kualitas dari akar, dan mendorong pengakaran yang seragam.

Zat pengatur tumbuh IAA pada waktu inisiasi akar paling banyak menumbuhkan akar dalam penelitian ini. Avivi (2005) dalam penelitiannya berpendapat bahwa pemberian auksin jenis IAA pada berbagai perlakuan memberikan pengaruh berbeda yang sangat nyata terhadap kedinian terbentuknya akar. Zong et al. (2008) bahwa peran utama auksin pada perbanyakan tanaman adalah menstimulasi akar pada stek batang dan daun serta meningkatkan cabang akar. Awal terbentuknya akar dimulai oleh adanya metabolisme cadangan nutrisi yang berupa karbohidrat yang menghasilkan energi yang selanjutnya mendorong pembelahan sel dan membentuk sel-sel baru dalam jaringan (Kastono et al, 2005). Pernyataan ini juga dikemukakan Davies (1995), bahwa auksin sangat 
diperlukan dalam pembentukan akar yakni memacu terjadinya pembelahan sel.

Tunas-tunas Dendrobium sp yang mengalami multiplikasi (tunas bertambah banyak dalam media tanam) dapat dilihat pada Gambar 1. Tunas-tunas Dendrobium sp yang ditanam dalam media tanam penginduksian akar mengalami multiplikasi (tunas bertambah banyak) terlebih dahulu, kemudian diikuti dengan adanya pertumbuhan akar pada tunas tersebut. Menurut Davies (2004), interaksi antara auksin dan sitokinin dalam kultur in vitro mampu membuat sel-sel pada jaringan tanaman mengalami proses pembelahan dan pembesaran, sedangkan pada media tanpa penambahan BAP, auksin pada tahap ini sudah mulai membentuk planlet.

Tabel 2 Konsentrasi MDA pankreas tikus Wistar pada berbagai variasi dosis pemberian minyak trans

\begin{tabular}{ll}
\hline Dosis minyak trans & Konsentrasi MDA pankreas $(\mu \mathrm{g} / \mathrm{g})$ \\
\hline Kontrol & $6.30 \pm 1.736$ \\
$20 \%$ energi total pakan & $7.65 \pm 2.099$ \\
$40 \%$ energi total pakan & $9.13 \pm 2.237$ \\
$60 \%$ energi total pakan & $9.46 \pm 0.760$ \\
\hline
\end{tabular}

Tunas-tunas Dendrobium sp yang telah memiliki akar dalam penelitian ini bisa dikatakan sebagai plantlet. Plantlet adalah tanaman lengkap (artinya memiliki akar, batang dan daun) hasil regenerasi dalam kultur jaringan atau disebut juga tanaman mini (Soerianegara, 1994). Berbagai jenis auksin dapat diaplikasikan bersama-sama atau dikombinasikan dengan golongan sitokinin dan giberelin (Jenes et al., 1977 dalam Ahmed et al., 2002). George dan Sherrington (1984) menyatakan bahwa BAP merupakan sitokinin yang banyak berperan dalam pembentukan dan penggandaan tunas dan pengaruhnya lebih kuat dibandingkan sitokinin lainnya seperti kinetin ataupun 2-iP. Peningkatan konsentrasi BAP cenderung menekan pertumbuhan akar karena BAP termasuk jenis sitokinin yang dapat menghambat inisiasi akar dan pertumbuhan akar, terutama bila diberikan dalam konsentrasi yang tinggi.

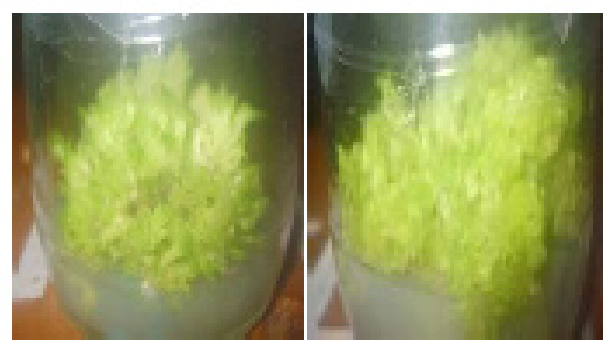

Gambar 1. Tunas Dendrobium sp yang mengalami multiplikasi pada media tanam tanpa penambahan ZPT (media kontrol).

\section{Panjang Akar}

Rata-rata panjang akar pada tunas Dendrobium sp secara statistik menunjukkan hasil yang beda nyata dengan menggunakan konsentrasi auksin yang berbeda pada media perlakuan. Ratarata panjang akar pada tunas Dendrobium sp secara statistik menunjukkan hasil yang beda nyata dengan menggunakan jenis auksin yang berbeda. Rata-rata panjang akar pada tunas Dendrobium sp dengan pemberian jenis auksin 2,4-D pada konsentrasi 0,75 ppm menunjukkan hasil rata-rata panjang akar paling tinggi diantara jenis dan konsentrasi auksin yang digunakan dapat terlihat pada 
Tabel 3. Pertumbuhan panjang akar dapat dipengaruhi oleh dua faktor, yaitu faktor genetik dan faktor jumlah daun. Faktor genetik berperan dalam mengkoordinasikan gen yang membangun sistem perakaran, sedangkan faktor jumlah daun bertanggung jawab dalam meningkatkan perkembangan akar, karena daun merupakan tempat sintesis makanan melalui proses fotosintesis, dan selanjutnya makanan akan ditranslokasikan menuju akar untuk perkembangan akar (Husain dan Khan, 2004).

\begin{tabular}{cccc}
\multicolumn{5}{c}{ Tabel 3. Rata-rata Panjang dan Jumlah Akar pada Tunas Dendrobium s } \\
\cline { 3 - 4 } No. & Media Perlakuan & \multicolumn{2}{l}{ Rata-rata } \\
\cline { 3 - 4 } & & Panjang Akar $(\mathrm{cm})$ & Jumlah Akar(helai) \\
\hline 1. & A0B0 & 0,7 & 0,7 \\
2. & A1B0 & 0,9 & 1,2 \\
3. & A2B0 & 1,0 & 1,2 \\
4. & A3B0 & 0,9 & 1,3 \\
5. & A0B1 & 0,8 & 1,0 \\
6. & A1B1 & 0,9 & 1,2 \\
7. & A2B1 & 1,0 & 1,3 \\
8. & A3B1 & 0,9 & 1,4 \\
9. & N0B0 & 0,7 & 0,7 \\
10. & N1B0 & 0,9 & 1,2 \\
11. & N2B0 & 0,9 & 1,2 \\
12. & N3B0 & 0,9 & 1,2 \\
13. & N0B1 & 0,7 & 0,7 \\
14. & N1B1 & 0,8 & 1,2 \\
15. & N2B1 & 0,8 & 1,2 \\
16. & N3B1 & 0,9 & 1,4 \\
17. & D0B0 & 0,7 & 0,7 \\
18. & D1B0 & 0,9 & 1,2 \\
19. & D2B0 & 0,8 & 1,0 \\
20. & D3B0 & 1,0 & 1,2 \\
21. & D0B1 & 0,7 & 0,7 \\
22. & D1B1 & 1,2 & 1,3 \\
23. & D2B1 & 0,9 & 1,2 \\
24. & D3B1 & 0,8 & 1,3 \\
\hline & & &
\end{tabular}

Air kelapa yang ditambahkan ke dalam media tanam diduga efektif dalam proses pemanjangan akar. Mandang (1993), menyatakan bahwa air kelapa dapat meningkatkan IAA dalam jaringan dan memenuhi kebutuhan pertumbuhan dan morfogenesis kultur. Menurut hasil penelitian

Pisesha, (2008), air kelapa mendorong pembentukan akar pada media MS yang dikombinasikan dengan IAA. Auksin endogen diduga cukup tinggi pada jaringan tanaman. Pada media tanpa penambahan air kelapa dan auksin, planlet masih memiliki kemampuan tumbuh. Diduga, sel-sel jaringan mampu membelah karena pengaruh auksin endogen. Menurut Gaba (2005) auksin endogen berperan dalam proses pembelahan sel.

Gambar 2 menunjukkan adanya pertumbuhan akar pada tunas Dendrobium sp yang ditanam dalam media dengan penambahan auksin jenis IAA, NAA dan 2,4-D. Akar yang tumbuh dalam media perlakuan merupakan akar tunggal yang terdapat pada tunas Dendrobium sp, tetapi ada juga media perlakuan dengan dua akar yang tumbuh pada tunas Dendrobium sp. Media perlakuan 
dengan penambahan auksin jenis 2,4-D menunjukkan bahwa akar tumbuh paling bagus diantara auksin jenis IAA dan NAA. Auksin jenis 2,4-D merupakan auksin sintetis yang memiliki sifat reaksi lebih besar daripada auksin jenis IAA dan NAA yang digunakan dalam penelitian ini. Auksin memiliki peranan yang penting dalam inisiasi akar pada kultur in vitro, hal ini dijelaskan oleh Woodward (2005) bahwa auksin berperan dalam memicu pembentukan akar lateral dari kalus yang belum terdiferensiasi, tetapi pada medium yang diberi paparan cahaya respon eksplan terhadap auksin menjadi berkurang.

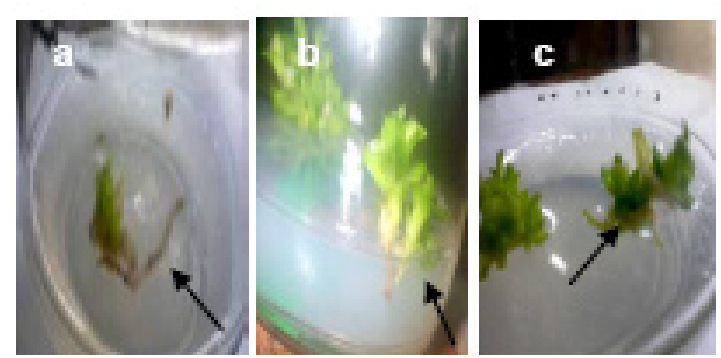

Gambar 2. Akar yang tumbuh pada media dengan penambahan auksin IAA (a), NAA (b) dan 2,4-D (c). Tanda panah hitam menunjukkan adanya akar pada tunas Dendrobium sp.

Panjang akar menunjukkan batas kemampuan tanaman untuk menjangkau wilayah tertentu dalam penyerapan unsur hara, sehingga semakin panjang akar memungkinkan tanaman untuk menyerap unsur hara, mineral dan air lebih banyak daripada akar yang pendek (Schuurman dan Goedewagen, 1971). Menurut Goldsworthy dan Fisher (1992) panjang akar telah diterima sebagai ukuran menilai daya penyerapan sistem akar. Tanaman yang memiliki akar yang panjang akan memiliki kemampuan menyerap hara dan air lebih baik bila dibandingkan dengan tanaman yang akarnya pendek dan mampu mencari air pada lokasi yang sulit untuk mencapai air. Semakin bertambah panjang akar maka tanaman akan lebih kokoh dan air serta garam-garam mineral di dalam media tumbuh akan mudah diserap untuk disalurkan ke batang dan daun.

\section{Jumlah Akar}

Secara statistik, jumlah akar pada tunas Dendrobium sp hasil induksi dengan perlakuan konsentrasi auksin sebesar 0 ppm; 0,75 ppm; 1,00 ppm dan 1,25 ppm dalam media menunjukkan hasil yang beda nyata terhadap jumlah akar tunas Dendrobium sp. Konsentrasi sitokinin yang digunakan dalam penelitian secara statistik menunjukkan hasil yang beda nyata dan berperan dalam pertumbuhan jumlah akar. Hal ini kemungkinan didalam tunas Dendrobium sp terdapat adanya auksin endogen yang bekerja secara sinergis dengan sitokinin sehingga tunas tumbuh akar serta dapat juga mempengaruhi jumlah akar yang tumbuh pada tunas. Rata-rata jumlah akar pada tunas Dendrobium sp dengan pemberian IAA 1,25 ppm dan NAA 1,25 ppm menunjukkan hasil rata-rata jumlah akar paling tinggi dan berbeda secara signifikan diantara jenis dan konsentrasi auksin yang digunakan dalam penelitian ini, seperti yang terlihat pada Tabel 3 .

Pada media tanpa penambahan ZPT, eksplan masih memiliki kemampuan untuk membentuk akar. Diduga bahwa sel-sel jaringan masih memiliki kemampuan berdiferensiasi membentuk akar karena adanya pengaruh auksin endogen. Perlakuan tanpa BAP $(0 \mathrm{ppm})$ ternyata memberikan jumlah akar pada tunas dan kecenderungan jumlah akar menurun atau tidak ada akar pada tunas 
dengan meningkatnya konsentrasi BAP. Keadaan ini membuktikan bahwa BAP mampu menekan pertumbuhan akar.

Jumlah akar yang banyak dapat mengoptimalkan penyerapan nutrisi yang ada pada media kultur. Nickell (1982) cit. Rahmaniar (2007) menyatakan bahwa auksin aktif yang digunakan untuk pembentukan akar adalah Naphthalene acetic acid (NAA) dan Indol Buteric acid (IBA). Beberapa jenis lain yang dapat digunakan adalah 2,4-D dan 2,4,5-T. Kedua jenis tersebut membentuk akar jika digunakan pada konsentrasi rendah. Tipe sistem perakaran yang dihasilkan juga tergantung dari zat pengatur tumbuh yang digunakan. Asam phenoxy pada 2,4-D dan 2,4,5-T menghasilkan sistem perakaran yang banyak, tebal dan kokoh. Sedangkan IBA menghasilkan sistem perakaran serabut yang kuat. Davies (1995) dan Himanen et al. (2002) menyatakan bahwa auksin memicu terjadinya pembelahan sel, sehingga diperlukan untuk pembentukan akar. Secara visual, akar yang terbentuk pada penelitian induksi perakaran tunas Dendrobium sp memiliki warna putih dan hijau tetapi ada juga akar pada tunas Dendrobium sp dengan warna kecokelatan. Tidak terdapat adanya bulu akar dan hanya terdapat adanya satu akar tunggal tetapi ada juga tunas Dendrobium sp yang terdapat adanya dua akar.

Sel-sel dalam eksplan diduga memiliki kemampuan untuk memproduksi auksin sendiri sehingga mampu mendorong proses metabolisme sel. Oleh karena itu, penambahan auksin pada media kultur akan menyebabkan interaksi yang tidak seimbang dengan auksin endogen dan tidak dapat menghasilkan jumlah akar yang lebih banyak (Mujiyanto, 2003 cit. Rahmaniar, 2007). Jumlah akar menunjukkan kemampuan dalam melakukan penyerapan unsur hara (Schuurman dan Goedewaagen, 1971). Tanaman dengan jumlah akar yang banyak akan meningkatkan penyerapan unsur hara dan air yang dapat mendukung pertumbuhan dari tanaman pula. Marsk et al. (2000) dan Howard (1996) dalam Octavia et al. (2003) menyatakan kemampuan plantlet untuk membentuk akar dipengaruhi oleh beberapa faktor termasuk perbedaan genotipnya, tingkat kematangan jaringan dan karakter fisiologis. Oleh karena itu plantlet memberikan respons berakar yang berbeda-beda. Berdasarkan sensitifitasnya plantlet terhadap hormon perakaran, Marks et al (2000) dalam Octavia et al (2003) menggolongkan ada tanaman yang mudah berakar dan tanaman yang sukar berakar. Hal ini penting untuk menentukan respons auksin secara eksogen ke dalam media tanam.

\section{Berat Total Tunas Dendrobium sp}

Perhitungan secara statistika pada berat total tunas Dendrobium sp dalam media perlakuan dengan jenis IAA, konsentrasi auksin 0,75 ppm; 1,00 ppm dan 1,25 ppm serta konsentrasi sitokinin 0 ppm dan media perlakuan dengan jenis IAA, konsentrasi auksin 0 ppm; 0,75 ppm; 1,00 ppm dan 1,25 ppm serta konsentrasi sitokinin sebesar $0,25 \mathrm{ppm}$ menunjukkan hasil yang berbeda nyata. Jenis auksin 2,4-D, konsentrasi 1,00 ppm dan 1,25 ppm menunjukkan hasil yang berbeda nyata pada rata-rata jumlah akar tunas Dendrobium sp.

Rahayu et al. (2003) menyatakan bahwa berat segar tunas yang besar ini disebabkan karena kandungan airnya yang tinggi. Pertumbuhan dan morfogenesis in vitro dipengaruhi oleh adanya interaksi dan perimbangan antara zat pengatur tumbuh yang ditambahkan dalam media dan hormon pertumbuhan yang dihasilkan secara endogenous oleh sel-sel yang dikultur (George dan Sherrington, 1984). Pertumbuhan dicirikan dengan bertambahnya berat yang irreversible, sehingga 
Tabel 3. Rata-rata Panjang dan Jumlah Akar pada Tunas Dendrobium sp

\begin{tabular}{|c|c|c|c|}
\hline \multirow[t]{2}{*}{ No. } & \multirow{2}{*}{ Media Perlakuan } & \multicolumn{2}{|l|}{ Rata-rata } \\
\hline & & Panjang Akar (cm) & Jumlah Akar(helai) \\
\hline 1. & $\mathrm{~A} 0 \mathrm{~B} 0$ & 0,7 & 0,7 \\
\hline 2 & $\mathrm{~A} 1 \mathrm{~B} 0$ & 0,9 & 1,2 \\
\hline 3. & $\mathrm{~A} 2 \mathrm{~B} 0$ & 1,0 & 1,2 \\
\hline 4. & A3B0 & 0,9 & 1,3 \\
\hline 5. & $\mathrm{~A} 0 \mathrm{~B} 1$ & 0,8 & 1,0 \\
\hline 6. & A1B1 & 0,9 & 1,2 \\
\hline 7. & $\mathrm{~A} 2 \mathrm{~B} 1$ & 1,0 & 1,3 \\
\hline 8. & A3B1 & 0,9 & 1,4 \\
\hline 9. & N0B0 & 0,7 & 0,7 \\
\hline 10. & N1B0 & 0,9 & 1,2 \\
\hline 11. & $\mathrm{~N} 2 \mathrm{~B} 0$ & 0,9 & 1,2 \\
\hline 12. & N3B0 & 0,9 & 1,2 \\
\hline 13. & N0B1 & 0,7 & 0,7 \\
\hline 14. & N1B1 & 0,8 & 1,2 \\
\hline 15. & N2B1 & 0,8 & 1,2 \\
\hline 16. & N3B1 & 0,9 & 1,4 \\
\hline 17. & D0B0 & 0,7 & 0,7 \\
\hline 18. & D1B0 & 0,9 & 1,2 \\
\hline 19. & $\mathrm{D} 2 \mathrm{~B} 0$ & 0,8 & 1,0 \\
\hline 20. & D3B0 & 1,0 & 1,2 \\
\hline 21. & D0B1 & 0,7 & 0,7 \\
\hline 22. & D1B1 & 1,2 & 1,3 \\
\hline 23. & $\mathrm{D} 2 \mathrm{~B} 1$ & 0,9 & 1,2 \\
\hline 24. & D3B1 & 0,8 & 1,3 \\
\hline
\end{tabular}

pengukuran berat segar kalus dapat mewakili variabel pertumbuhan kalus yang berasal dari tunas tanaman Dendrobium sp. Menurut Ruswaningsih (2007), berat segar secara fisiologis terdiri dari dua kandungan yaitu air dan karbohidrat. Berat total tunas pada Dendrobium sp bertambah setelah masa pengamatan selesai dilakukan dengan melakukan penimbangan terhadap tunas yang tumbuh dalam media tanam pada minggu terakhir pengamatan.

Persentase pertambahan berat tunas Dendrobium sp paling baik terdapat pada media perlakuan jenis IAA 1,25 ppm dan BAP 0 ppm dengan persentase berat basah paling tinggi yaitu sebesar $88,22 \%$. Berat basah yang dihasilkan sangat tergantung pada kecepatan sel-sel tersebut membelah diri, memperbanyak diri dan dilanjutkan dengan membesarnya tunas. Media dengan penambahan auksin jenis IAA lebih banyak menunjukkan persentase pertambahan berat basah tunas lebih baik dibandingkan dengan auksin jenis NAA dan 2,4-D. Media perlakuan dengan jenis NAA 1,00 ppm BAP 0,25 ppm merupakan media dengan berat basah tunas Dendrobium sp paling kecil yaitu sebesar 31,66\%, seperti yang terlihat pada Tabel 4. Auksin dan sitokinin yang digunakan dalam media bersifat sinergis. Auksin berperan

dalam mengatur pertumbuhan dan pemanjangan sel, sedangkan sitokinin berperan dalam pembelahan sel. Hal ini mudah dimengerti karena secara seluler auksin berperan dalam pemanjangan sel, sedangkan sitokinin memicu pembelahan sel, morfogenesis dan pengaturan pertumbuhan merupakan proses yang sangat penting dalam pembentukan kalus dan selanjutnya 
diikuti rediferensiasi kalus menuju pembentukan tunas yang dipicu oleh adanya cahaya. Hal ini diperkuat oleh Kusumo (1984) dalam Maryani (2005) yang menunjukkan bahwa sitokinin dan auksin berperan saling melengkapi dalam menginduksi tunas. Penambahan air kelapa ke dalam media perlakuan diduga mempengaruhi pertambahan berat pada tunas Dendrobium sp.

Menurut Davies (2004), interaksi auksin dan sitokinin dalam kultur in vitro mampu membuat sel-sel pada jaringan tanaman mengalami proses pembelahan dan pembesaran, sedangkan pada media tanpa penambahan BAP, auksin pada tahap ini sudah mulai membentuk planlet. Penambahan perlakuan BAP dalam media tanam dapat meningkatkan jumlah tunas dan daun serta mempunyai kecenderungan menurunkan jumlah akar dan tinggi tunas (Tjandra, 2000 dalam Kurniawati, 2004). Penelitian ini juga menambahkan air kelapa dalam media perlakuan. Morel (1974) dalam Parera (1997), mengatakan bahwa air kelapa mampu menstimulir pembelahan sel epidermis dan mengarah pada pembentukan protocrom jaringan supaya beregenerasi lebih lanjut dan lebih cepat. Armini et al., (1991), juga menyatakan bahwa perbandingan auksin dan sitokinin yang digunakan mempengaruhi pembentukan tunas dan akar dalam kultur jaringan.

Perbandingan antara sitokinin dan auksin yang tinggi akan mendorong pembentukan tunas, sedangkan perbandingan sitokinin dan auksin rendah akan mendorong pembentukan akar, sehingga selain meningkatkan jumlah tunas terbanyak juga dapat meningkatkan aktifitas sitokinin yang selanjutnya meningkatkan efektifitas pembelahan sel semakin tinggi, sebab air kelapa adalah endosperm yang kaya akan makanan, maka jika air kelapa tersebut ditambahkan dalam media kultur jaringan, eksplan yang ditanam dapat tumbuh dengan baik.

\section{KESIMPULAN}

1. Jenis dan konsentrasi auksin yang paling baik dalam menginduksi perakaran pada tunas Dendrobium sp adalah 2,4-D pada konsentrasi 0,75 ppm.

2. Rata-rata panjang akar paling banyak terdapat pada media perlakuan 2,4-D 0,75 ppm, sedangkan rata-rata jumlah akar paling banyak terdapat pada media perlakuan IAA dan NAA dengan konsentrasi 1,25 ppm.

\section{IMPLIKASI}

Perlu adanya pengkajian ulang materi dalam penggunaan jenis dan konsentrasi auksin, konsentrasi sitokinin dan air kelapa dalam penelitian yang akan datang untuk mendapatkan kombinasi perlakuan yang tepat dalam penginduksian perakaran pada tanaman anggrek lainnya.

\section{SARAN}

Perlu diadakan teknik penginduksian akar yang lebih efektif untuk memperoleh plantlet dalam jumlah banyak dan waktu yang singkat serta untuk mendapatkan kombinasi jenis dan konsentrasi auksin yang tepat untuk induksi perakaran.

\section{DAFTAR PUSTAKA}


Ahmed, E. E., GY.D. Bisztray and I. Velich, 2002. Plant regeneration from seedling explants of common bean (Phaseolus vulgaris L.). Proceedings of the 7 th Hungarian Congress on Plant Physiology. Szent Istvan University of Budapest. Budapest, Hungary. 115 - 123.

Armini, N. M, G. A. Wattimena dan L. W. Gunawan. 1991. Bioteknologi Tanaman. Pusat Antar Universitas.Institut Pertanian Bogor. Bogor.

Avivi, S. dan Parawita D. 2005. Jurnal Teknologi Produksi Bibit Melon (Cucumis melo L.) dengan Teknik In-Vitro. Diakses pada tanggal 30 September 2013.

Davies, P. J., 1995. Plant Hormones: Physiology, Biochemistry and Molecular Biology. Kluwer Academic Publishers. Dordrecht/ Boston/ London. 1-33.

Davies, P. J. 2004. Plant Hormones : Biosynthesis, Signal Transduction, Action. Kluwer Academic Publisher. London.

Fatmawati, A. 2008. Kajian Konsentrasi BAP dan 2,4-D terhadap Induksi Kalus Tanaman Artemisia annua L. secara In Vitro. Skripsi Fakultas Pertanian UNS. Surakarta.

Gaba, V. B. 2005. Plant Growth Regulators in Plant Tissue Culture and Development. In : Trigiano and Gray. Plant Development and Biotechnology. CRC Press. London.

George, E. F. dan Sherrington, 1984. Plant Propagation by Tissue Culture Handbook and Directory of Commercial Laboratories Exegetics Ltd. Erasley. Bassingtone. England. 551pp.

Goldsworthy, P. R. dan N. M. Fisher. 1992. Fisiologi Tanaman Budidaya Tropika. Gadjah Mada University Pr. Yogyakarta. 874 hal.

Hanifah, N. 2007. Pengaruh Konsentrasi NAA dan BAP terhadap Pertumbuhan Eksplan Jarak Pagar (Jatropha curcas L.) secara In Vitro. Skripsi Fakultas Pertanian UNS. Surakarta.

Himanen, K., E. Boucheron, S. Vannesse, J. de Almeida-Engler, D. Inze and T. Beeckman, 2002. Auxin Mediated Cell Cycle Activation During Early Root Initiation. Plant Cell 14 (10) : 2339 - 2352.

Hussain, A and Khan, M.A. 2004. Effect of Growth Regulator on Stem Cutting of Rosa bourboniana and Rosa gruss-anteplitz. International Journal of Agriculture \& Biology. 6(5):931-932.

Indarto, Novo. 2011. Pesona Anggrek : Petunjuk Praktis Budi Daya dan Bisnis Anggrek. Cahaya Atma Pustaka. Yogyakarta.

Kastono, D., Sawitri, H., dan Siswandono. 2005. Pengaruh Nomor Ruas Stek dan Dosis Pupuk Urea Terhadap Pertumbuhan dan Hasil Kumis Kucing. Jurnal Ilmu Pertanian.12(1):5664.

Kurniawati, M. 2004. Pengaruh 2,4-D, BAP, dan Kinetin untuk Induksi Kalus Tunas Mentha arvensis Var. Tempaku. Skripsi. Departemen Biologi. Fakultas Matematika dan Ilmu Pengetahuan Alam. Institut Pertanian Bogor. Bogor.

Macdonald, B. 2002 Practical Woody Plant Propagation for Nursery Growers. Volume 1. Timber press, Inc. (portland, orego). $669 \mathrm{p}$.

Mandang, J. P. 1993. Peranan Air Kelapa Dalam Kultur Jaringan Tanaman Krisan (Chrysanthemum morifolium Ramat). Disertasi. Institut Pertanian Bogor. Bogor.

Maryani, Yekti dan Zamroni. 2005. Penggandaan Tunas Krisan Melalui Kultur Jaringan. Ilmu Pertanian Vol. 12 No.1, 2005: 51-55.

Octavia, F., Siswanto, A., Budiani dan Sudarsono, 2003. Embriogenesis Somatik Langsung 
dan Regenerasi Plantlet Kopi Arabika (Coffea arabica) dari Berbagai Eksplan. Menara Perkebunan, 2003. 71(2). P. 44-55.

Parera, Dj. F. 1997. Pengaruh Tingkat Konsentrasi Air Kelapa terhadap Pertumbuhan dan Perbanyakan Tanaman Anggrek Dendrobium spp melalui Teknik Kultur

Jaringan. GOTI-Jurnal Ilmu Pengetahuan dan Teknologi, Universitas Pattimura, Vol. 2

Pisesha, P. A. 2008. Pengaruh Konsentrasi IAA, IBA, BAP dan Air Kelapa Terhadap Pembentukan Akar Poinsettia (Euphorbia pulcherrima Wild Et Klotzch) In Vitro. Skripsi. Departemen Agrikultur dan Hortikultura. Fakultas Pertanian. Institut Pertanian Bogor. 40 hal.

Rahayu, B., Solichatun dan E. Anggarwulan. 2003. Pengaruh Asam 2,4-Diklorofenoksiasetat (2,4-D) terhadap Pembentukan dan Pertumbuhan Kalus serta Kandungan Flavonoid Kultur Kalus Acalypha indica L. Biofarmasi 1(1): 1-6.

Rahmaniar, A. 2007. Pengaruh Macam Eksplan dan Konsentrasi 2,4-D-Dichlorophenoxyacetic Acid (2,4-D) terhadap Pertumbuhan Anthurium (Anthuriumm plowmanii Croat) pada Medium MS. Skripsi. Fakultas Pertanian UNS. Surakarta.

Ruswaningsih, F. 2007. Pengaruh Konsentrasi Ammonium Nitrat dan BAP terhadap Pertumbuhan Eksplan Pucuk Artemisia annua L. pada Kultur In Vitro. Skripsi. Fakultas Pertanian UNS. Surakarta.

Schuurman, J. J. and M. A. J. Goedewaagen. 1971. Methods for the Examintation of Root Systems and Roots. Centre for Agricultural Pub. And Documentation. 86p.

Soerianegara, I. 1994. Teknologi Kultur Jaringan. Badan Penelitian dan Pengembangan Departemen Kehutanan. Jakarta.

Woodward, Andrew W and Bartel, Bonnie. 2005. Auxin: Regulation, Action, and Interaction. Department of Biochemistry and Cell Biology, Rice University USA. Annals of Botany 95: 707-735, 2005.

Zong M. C., Yi Li and Zhen Z. 2008. Plant Growth Regulators Used in Propagation. p. 143-150. Plant Propagation, Concepts and Laboratory Exercices. CRC Press. 